\title{
Årsberetning for 1984-85
}

I 1984 blev Grundtvig-Selskabets årsmøde afholdt på Lysebu nord for Oslo i dagene 30. april til 2. maj. Ved det velbesøgte og spændende møde talte professor Gustav Albeck om nordmænds syn på den unge Grundtvig, og i Kampen Kirke blev der ved sognepræst Kirsti Aasens mellemkomst afholdt en salmesangsaften. Ligeledes i Kampen Kirke holdtes den 1. maj en gudstjeneste med docent Berge Furre som prædikant, hvorefter man besøgte Gammel Aker Kirke med prof. Albeck som guide. Senere samme dag talte universitetslektor Erling Nielsen om Grundtvig og Norge og konsulent cand. theol. Olav Akerlie om norsk folkehøjskole og Grundtvig 1984. Med henblik på aktuelle norske forhold talte universitetslektor Jørgen Stenbæk, Århus, den sidste formiddag om Grundtvigs kirkelige frihedstanker og den senere kirkelige lovgivning i Danmark. Herefter drøftedes de særlige forhold for den norske afdeling af Grundtvig-Selskabet. Selskabet har siden 1983 fået op imod 100 norske medlemmer.

I det forløbne år har Grundtvig-Selskabet fra Statens humanistiske Forskningsråd fået $5.000 \mathrm{kr}$. som støtte til udgivelsen af Grundtvig-Studier samt fra Grundtvig-Fonden ialt $5.000 \mathrm{kr}$. bl.a. som støtte til bestræbelserne for at udbrede kendskabet til Grundtvig i Norge. Formanden har også søgt og fra GrundtvigFonden fået $5.000 \mathrm{kr}$. til Jørn Bergmann og hans firma AKAprint aps, der med stor økonomisk risiko har udsendt den smukke facsimile-udgave af Danne-Virke bind 1-4. Sidenhen har Kirkeligt Samfund af 1898 (Farvergade 27, 1463 Kbh. K.) erhvervet restoplaget; her kan værket erhverves for $300 \mathrm{kr}$. Professor Theodor Jørgensen oplyser, at der stadig arbejdes med at få udgivet et udvalg af Grundtvigs skrifter på tysk. 